\title{
Controlled Tautomeric Switching in Azonaphthols Tuned by Substituents on the Phenyl Ring
}

\author{
Liudmil Antonov, ${ }^{*[a]}$ Vera Deneva, ${ }^{[a, b]}$ Svilen Simeonov, ${ }^{[a]}$ Vanya Kurteva, ${ }^{[a]}$ Aurelien Crochet $^{[b]}$ \\ Katharina M. Fromm, ${ }^{[b]}$ Boris Shivachev, ${ }^{[c]}$ Rositsa Nikolova, ${ }^{[c]}$ Marika Savarese, ${ }^{[d]}$ and \\ Carlo Adamo ${ }^{[\mathrm{d}, \mathrm{e}]}$
}

\begin{abstract}
A series of new tautomeric azonaphthols are synthesized and the possibilities for molecular switching are investigated using molecular spectroscopy, X-ray analysis and density functional theory quantum chemical calculations. Two opposite effects that influence switching are studied: attaching a piperidine sidearm, and adding substituents to the phenyl ring. On the one hand, the attached piperidine moiety stabilizes the enol form leading to a controlled shift of the equilibrium upon protonation. On the other hand, the relative stability of the azonaphthol tautomers strongly depends on the effects of the substituents on the phenyl ring: electron donors tend to stabi-
\end{abstract}

\section{Introduction}

A molecular switch can toggle between two structures-the "on" and "off" states ${ }^{[1]}$ - that have different molecular properties. Single molecules can be used as molecular switches if they are able to fulfill certain conditions: 1) the molecule undergoes a change between two states when acted upon by different stimuli (e.g. light, $\mathrm{pH}$ change, electrical current) and 2) these changes must be reproducible and reversible. ${ }^{[2]}$ Tautomeric proton transfer seems to be a suitable process that fulfills these requirements, because it represents a fast and clean interconversion between two structurally different molecular

[a] Prof. Dr. L. Antonov, Dr. V. Deneva, Dr. S. Simeonov, Prof. Dr. V. Kurteva Institute of Organic Chemistry with Centre of Phytochemistry Bulgarian Academy of Sciences

Acad. G. Bonchev str., bl. 9, 1113 Sofia (Bulgaria)

E-mail:lantonov@orgchm.bas.bg

[b] Dr. V. Deneva, Dr. A. Crochet, Prof. Dr. K. M. Fromm Department of Chemistry

University of Fribourg

Chemin du Musée 9, 1700 Fribourg (Switzerland)

[c] Dr. B. Shivachev, Prof. Dr. R. Nikolova

Institute of Mineralogy and Crystallography "Acad. Ivan Kostov" Bulgarian Academy of Sciences

Acad. G. Bonchev str., bl. 107, 1113 Sofia (Bulgaria)

[d] Dr. M. Savarese, Prof. Dr. C. Adamo

Institut de Recherche de Chimie Paris IRCP

PSL Research University

CNRS_Chimie ParisTech, 11 rue Pierre et Marie Curie, 75005 Paris (France)

[e] Prof. Dr. C. Adamo

Institut Universitaire de France

103 Boulevard Saint Michel, 75005 Paris (France)

Supporting Information for this article is available lize the enol tautomer, whereas electron acceptors lead to stabilization of the keto form. However, these effects do not shift fully the equilibrium towards either of the tautomers. Nevertheless, the effect of the substituents can be an additional tool to affect the switching between "on" and "off" states. Electronwithdrawing substituents stabilize the keto form and impede switching to the off state, whereas electron donors stabilize the enol form. The effect of the piperidine unit is dominant overall, and with strongly electron-withdrawing substituents at the phenyl ring, the enol form exists as a zwitterion.

states, each of them with different molecular properties. ${ }^{[3]}$ Several tautomeric systems that exhibit switching properties have been reported ${ }^{[4]}$ However, the main challenge in the development of such switches is how to control the tautomeric proton transfer in solution. In other words, a protocol for the controlled shift of the tautomeric equilibrium must be developed to represent on and off states by individual tautomers.

Recently, we have designed a switch, in which a side moiety is connected to a unit that undergoes tautomerism, and the tautomeric proton becomes part of a stabilizing, intramolecular hydrogen-bonding system, which leads to a full shift of the equilibrium to the enol tautomer (the off state). In this tautomeric molecular switch $(\mathbf{1}$, Scheme 1$),{ }^{[5]}$ shifts in the position of the tautomeric equilibrium can be directed towards on/off states through protonation/deprotonation. Such design allows control over the proton-transfer process, although it is impossible to control the tautomeric behavior in the parent structure $(5){ }_{1}^{[5]}$ due to the moderate energy gap between the tautomers $5 \mathrm{E}$ and $5 \mathrm{~K}$.

It is well known that the relative stability of the azonaphthol tautomers strongly depends on the effects of the substituents in the phenyl ring. ${ }^{[6]}$ The electron donors stabilize the enol tautomeric form, whereas acceptors lead to stabilization of the keto form, ${ }^{[7]}$ but these effects do not fully shift the equilibrium towards either tautomer. Nevertheless the effect of the substituents can be an additional influence on switching between the on and off states in compounds derived from 1. As shown in Scheme 2, the electron-withdrawing groups (EWG) stabilizing the keto form should impede switching to the off state, whereas electron-donating groups (EDG) stabilize the enol 


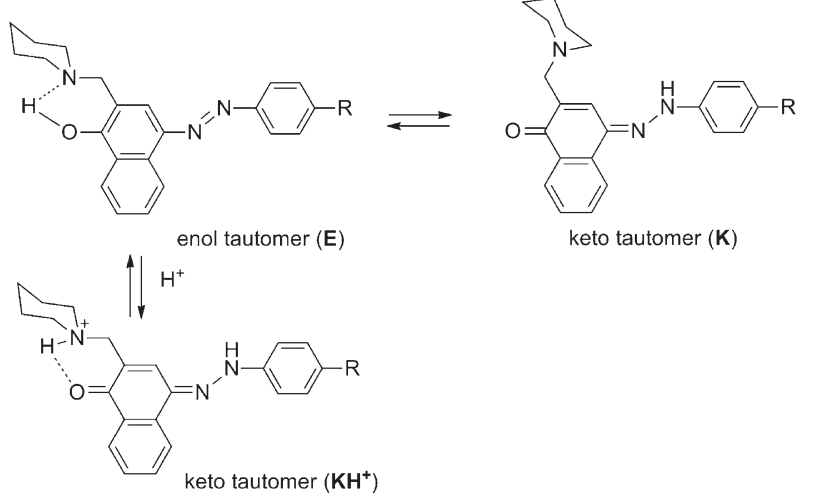

$\mathrm{R}=\mathrm{H}(1) ; \mathrm{OMe}(2) ; \mathrm{CN}(3) ; \mathrm{NO}_{2}(4)$

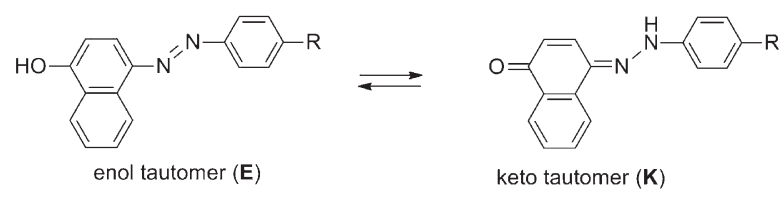

$\mathrm{R}=\mathrm{H}(5) ; \mathrm{OMe}(\mathbf{6}) ; \mathrm{CN}(7) ; \mathrm{NO}_{2}(\mathbf{8})$.

Scheme 1. Tautomeric equilibria of the investigated compounds.

form, making switching to the on state less favorable. In this article, we report several new compounds derived from structure 1, synthesized to study these controversial effects in detail, and explore the electronic effect of the substituents on the switching abilities.

\section{Results and Discussion}

Compounds 2-4 and 6-8 were investigated in acetonitrile using UV/Vis spectroscopy. As expected, the addition of a methoxy group to the phenyl ring stabilizes the enol form in both 2 and 6 (Figure 1), exhibiting a major absorbance at $400 \mathrm{~nm}$. However, in case of 6 the tautomeric equilibrium is not fully shifted, and a low-intensity band around $500 \mathrm{~nm}$ is observed, corresponding to the keto tautomer. ${ }^{[8]}$ The piperidine moiety of $\mathbf{2}$ stabilizes exclusively the enol form and the keto band is

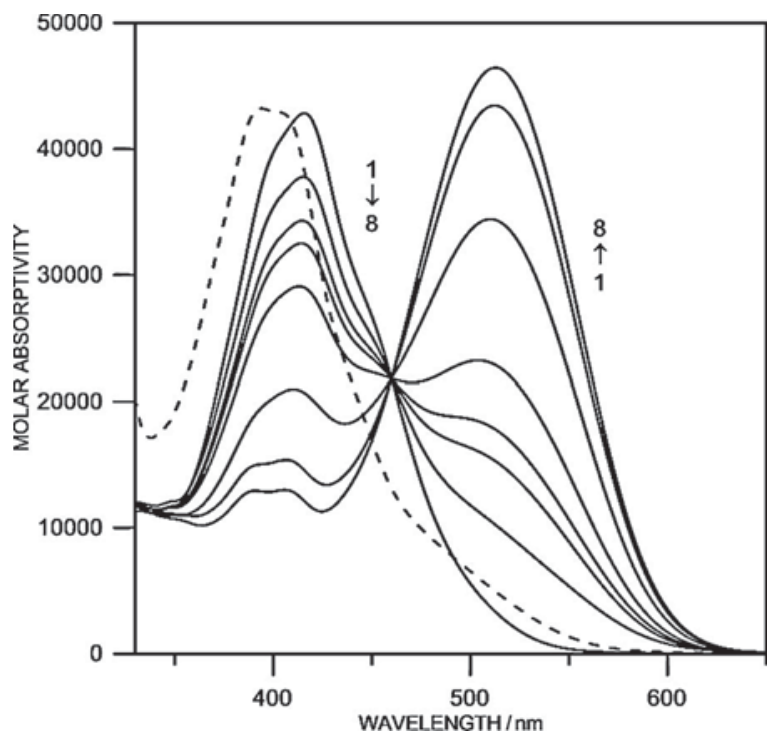

Figure 1. UV/Vis spectrum of 6 in anhydrous acetonitrile (-----) and spectrophotometric titration of $\mathbf{2}(-)$ with $\mathrm{H}_{2} \mathrm{SO}_{4}$ in anhydrous acetonitrile at $\mathrm{pH} 6.63,6.36,5.10,4.89,4.48,3.16,3.08$, and 2.85 .

absent. Although the switching is hampered by electron-donation of the substituent on the phenyl ring, as suggested in Scheme 2, switching is possible in acetonitrile and the intensity of the band of the protonated species $2 \mathrm{H}^{+}$increases at around $520 \mathrm{~nm}$ upon addition of acid (Figure $2 \mathrm{a}$ ). As expected, the piperidine moiety in $2\left(\mathrm{p} K_{\mathrm{a}}=5.54 \pm 0.02\right)$ is protonated to a lesser extent compared to that in $1\left(\mathrm{p} K_{\mathrm{a}}=5.89 \pm 0.05\right){ }_{1}{ }^{[4]}$ but it is able to overcome the opposite effect of the donor substituent in the process of switching. In contrast to 6 , the keto form of 7, absorbing at $450 \mathrm{~nm}$ (Figure $2 \mathrm{~b}$ ), is predominant. Interestingly, the absorption spectra in acetonitrile of $\mathbf{3}$ undergoing switching (Figure 2a) show an additional bathochromic peak at approximately $550 \mathrm{~nm}$, which cannot be attributed to either tautomeric form. This band disappears upon lowering the $\mathrm{pH}$, giving rise to the band corresponding to the pure keto form at $480 \mathrm{~nm}$; at pH 4.29 this process is fully complete, with the equilibrium fully shifted to the keto tautomer (Figure $2 \mathrm{a}$ ).
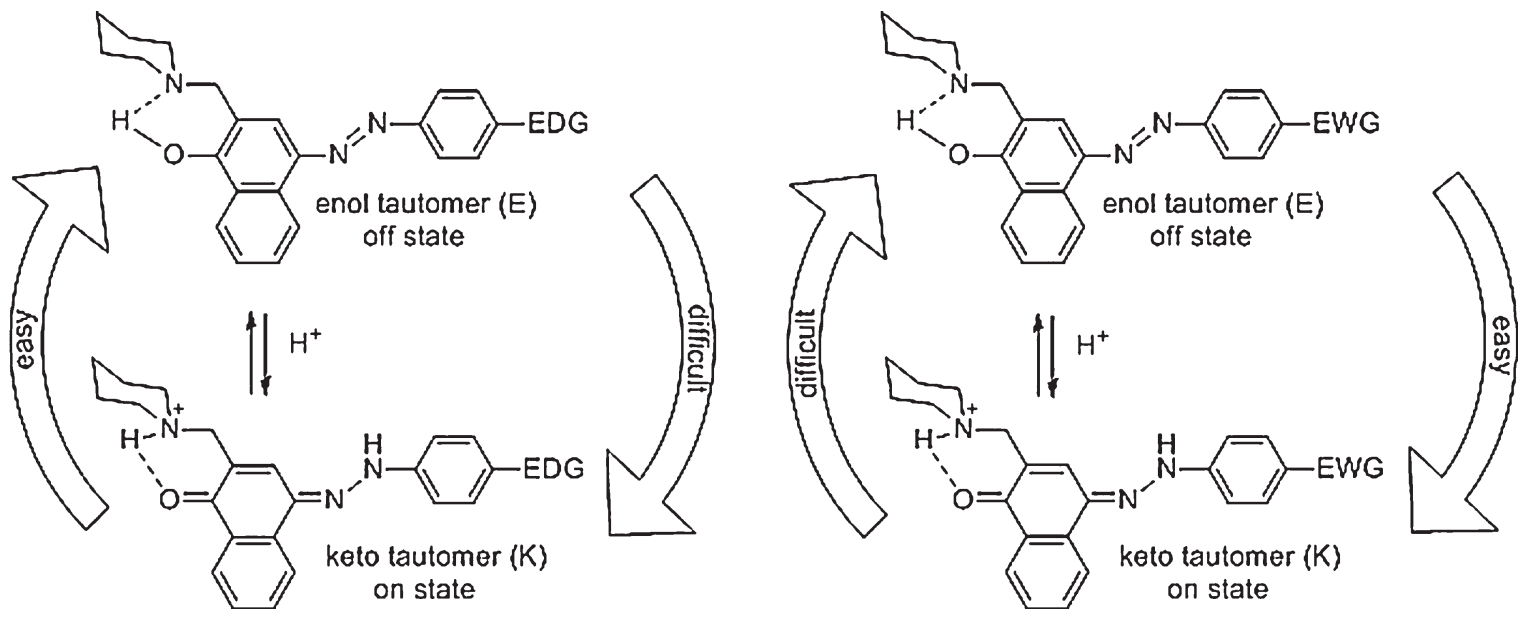

Scheme 2. General concept of the tautomeric switch.

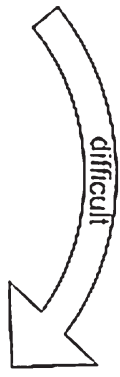




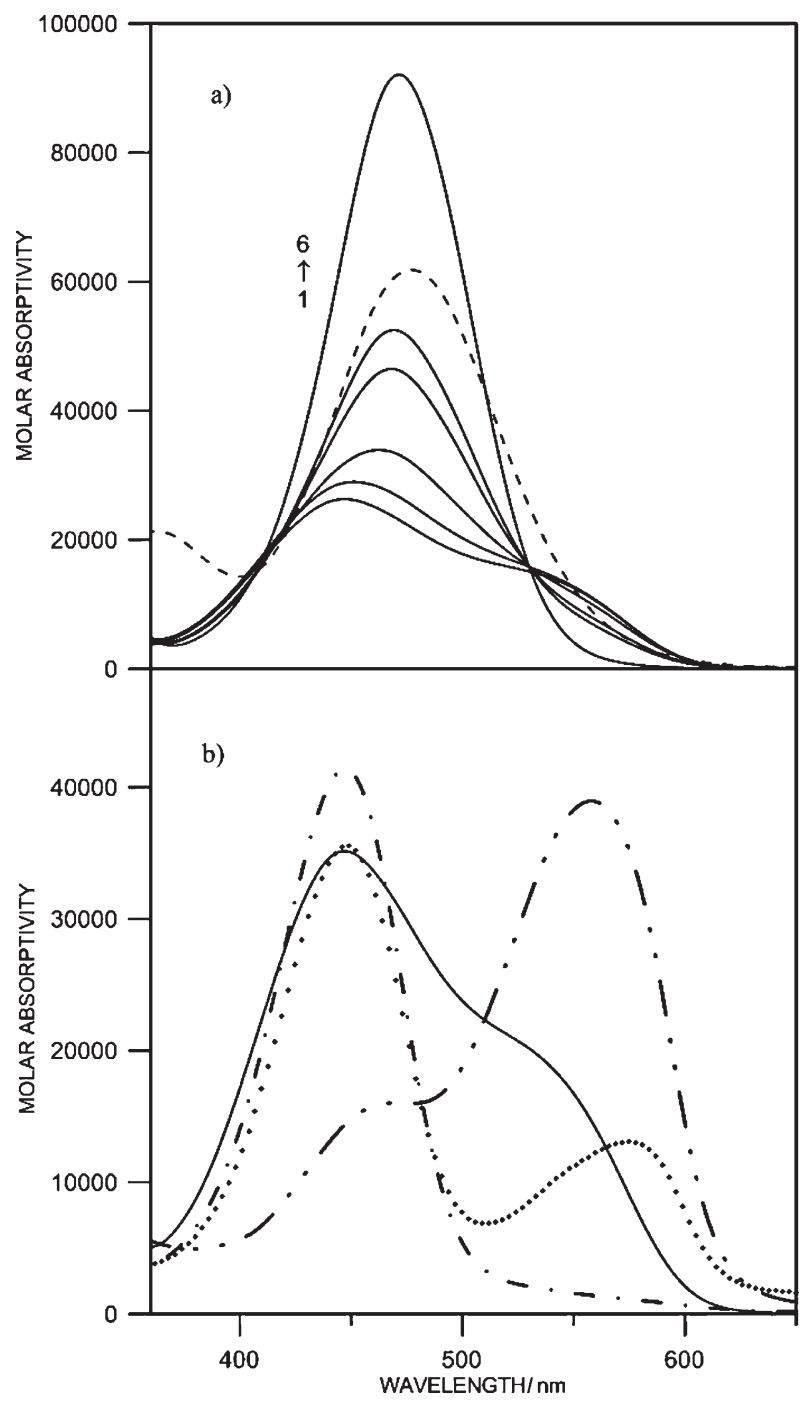

Figure 2. a) Spectrophotometric titration of 3 with $\mathrm{H}_{2} \mathrm{SO}_{4}$ in anhydrous acetonitrile ( $\mathrm{pH}$ values: 6.72, 6.46, 6.02, 5.73, 5.43, 4.29). Qualitative spectrum (due to poor solubility) of $\mathrm{N}$-Me derivative of 7 (---.-; Scheme 3). b) Absorption spectra of $\mathbf{3}$ in acetonitrile at pH $6.72(-), 7$ in the neutral state (-----), 7 with addition of $\mathrm{NH}_{4} \mathrm{OH}$ at $\mathrm{pH} 11.39$ (-.-) and 7 with addition of piperidine $(\diamond)$.

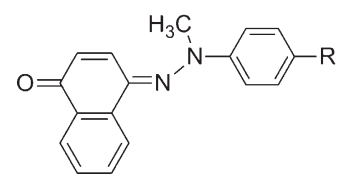

Scheme 3. Structure of fixed keto tautomers ( $\mathrm{N}$-Me derivative) of 2-4.
This conclusion is supported by the fact that, as shown in Figure $2 \mathrm{a}$, the maximum absorption of the keto form of $\mathbf{3}$, at approximately $480 \mathrm{~nm}$, coincides with the band of the $\mathrm{N}$-Me derivative of 7 (Scheme 3). Similar spectral behavior was observed for the pair 4 and 8.

The appearance of the band at $550 \mathrm{~nm}$ might be explained by the strongly EWG in the neutral molecule. According to the experimental data from solution, such substituents shift the equilibrium substantially towards the keto form in the parent backbone tautomers without a side moiety. ${ }^{[6]}$ However, the presence of the piperidine moiety leads to an opposite trend of stabilization of the enol form. The net effect of these two opposing tendencies is that the tautomeric equilibrium is shift-

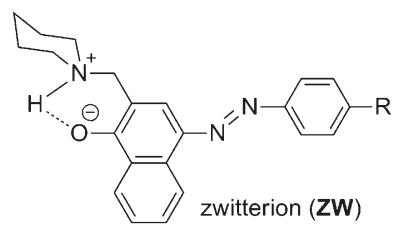

Scheme 4. Possible zwitterionic structure of 2-4.

ed to the enol form, but the $\mathrm{O}-\mathrm{H}$ bond is weakened. Therefore, it is likely that the tautomeric $\mathrm{H}$ atom migrates to the neighboring $\mathrm{N}$ atom of the piperidine unit to form a zwitterionic structure as suggested in Scheme 4. This assumption was given credence by the addition of piperidine to a solution of the parent compound 7, resulting in the appearance of a bathochromic band around $550 \mathrm{~nm}$ that coincides with the deprotonated form of 7 (Figure $2 \mathrm{~b}$ ), which is the closest structure to the suggested zwitterion shown in Scheme 4.

The predicted long-wavelength absorption maxima, compared with experimental maxima (Table 1), are also consistent with the suggested structure and observed spectral changes. Although M06-2X systematically underestimates the absorption maxima of the azo compounds, ${ }^{[9]}$ it is clear that the absorbance of zwitterionic structures should be red-shifted compared to the band of the keto tautomer.

\begin{tabular}{|c|c|c|c|}
\hline \multirow[t]{2}{*}{ Structure } & \multicolumn{3}{|c|}{$\lambda_{\max }[\mathrm{nm}]$} \\
\hline & Observed & Calculated & Predicted $^{[a]}$ \\
\hline $1 \mathrm{E}$ & 417 & 386 & 419 \\
\hline $1 \mathrm{~K}$ & - & 417 & - \\
\hline $1 \mathrm{EH}^{+}$ & - & 362 & - \\
\hline $1 \mathrm{KH}^{+}$ & 495 & 444 & 496 \\
\hline $1 \mathrm{ZW}$ & - & 437 & - \\
\hline $5 \mathrm{E}$ & 408 & 372 & 400 \\
\hline $5 \mathrm{~K}$ & 468 & 416 & 458 \\
\hline $2 E$ & 419 & 391 & 425 \\
\hline $2 \mathrm{~K}$ & - & 437 & - \\
\hline $2 \mathrm{EH}^{+}$ & - & 374 & - \\
\hline $2 \mathrm{KH}^{+}$ & 517 & 471 & 532 \\
\hline $2 \mathrm{ZW}$ & - & 434 & - \\
\hline $6 \mathrm{E}$ & 412 & 379 & 409 \\
\hline $6 \mathrm{~K}$ & 495 & 437 & 486 \\
\hline $3 \mathrm{E}$ & 444 & 413 & 454 \\
\hline $3 K$ & - & 409 & - \\
\hline $3 \mathrm{EH}^{+}$ & - & 380 & - \\
\hline $3 \mathrm{KH}^{+}$ & 472 & 435 & 484 \\
\hline $3 Z W$ & 555 & 479 & 448 \\
\hline $7 E$ & 429 & 395 & 430 \\
\hline $7 \mathrm{~K}$ & 459 & 408 & 448 \\
\hline $4 \mathrm{E}$ & 466 & 427 & 473 \\
\hline $4 \mathrm{~K}$ & - & 413 & - \\
\hline $4 \mathrm{EH}^{+}$ & - & 388 & - \\
\hline $4 \mathrm{KH}^{+}$ & 472 & 435 & 484 \\
\hline $4 Z W$ & 593 & 511 & 585 \\
\hline $8 \mathrm{E}$ & 435 & 407 & 446 \\
\hline $8 \mathrm{~K}$ & 468 & 411 & 452 \\
\hline
\end{tabular}

[a] Predicted using the linear regression between observed and calculated values given in Figure S25. 

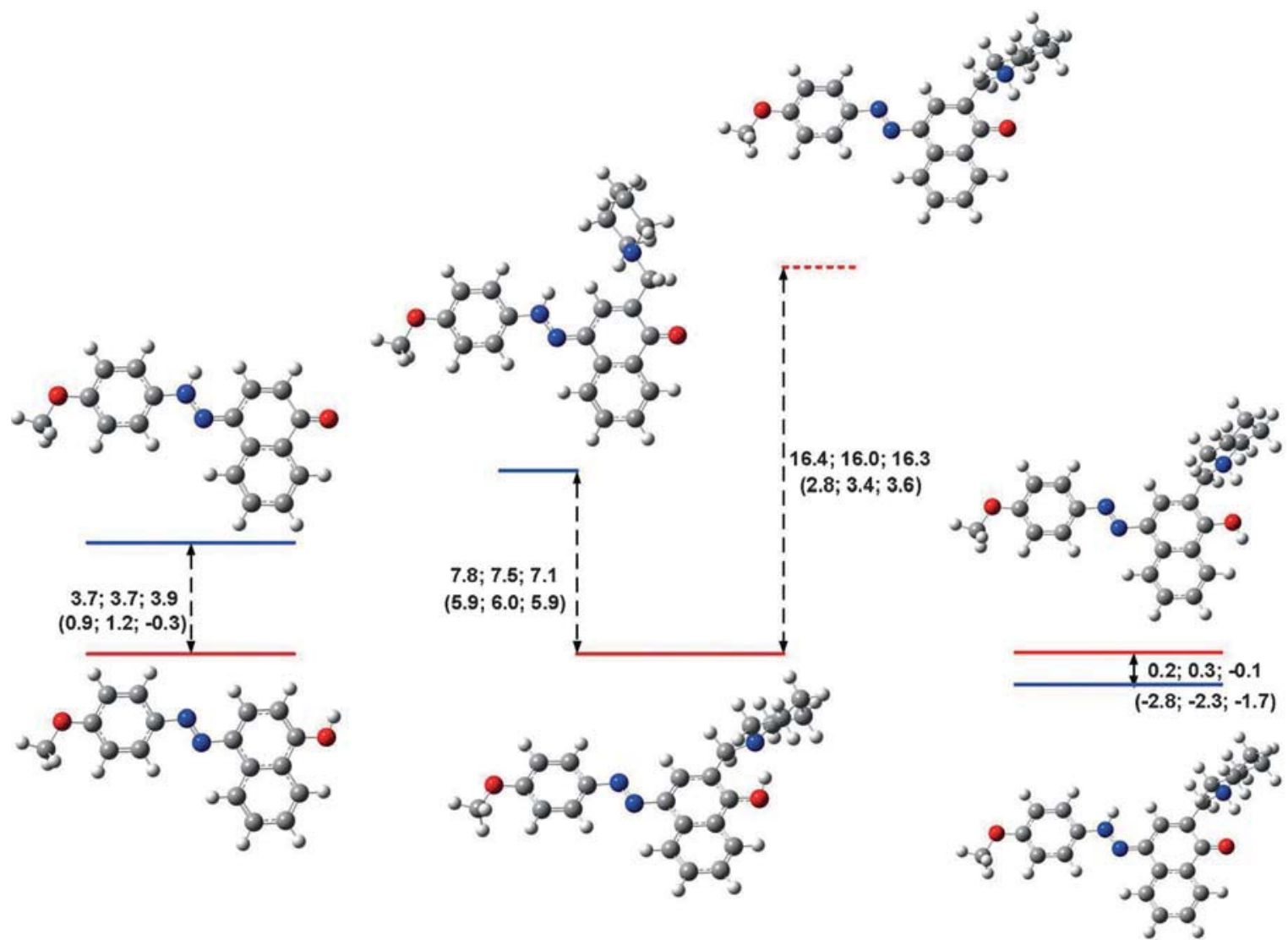

Figure 3. Change in the relative energy (M06-2X/def2-TZVP) of the tautomers of the parent compound 6 (left), 2 (center) and $\mathbf{2} \mathbf{H}^{+}$(right) in the gas phase. The values of $\Delta E, \Delta E+Z P E$ and $\Delta \Delta G$ are expressed in $\mathrm{kcal} \mathrm{mol}^{-1}$ units. The corresponding values obtained using a PCM solvent description in acetonitrile are given in brackets.

The observed spectral data are well described by the quantum chemical calculations (Figures 3-5 and Figures S26-S27 in the Supporting Information). The intramolecular hydrogen bonding between the tautomeric $\mathrm{H}$ atom and the piperidine moiety in the neutral compound 2 widens the energy gap to $7.8 \mathrm{kcal} \mathrm{mol}^{-1}$ compared to 6 , which suggests a shift of the tautomeric equilibrium to the enol form (Figure 3 , in the gas phase and acetonitrile). In this case, if we compare 2 and 1 , $^{[4]}$ both effects-the substituent on the phenyl ring and the piperidine moiety effect-lead to a shift of the equilibrium to the enol form (Scheme 2). Upon addition of acid the tautomeric equilibrium fully shifts to the keto form, which is stabilized by $-2.8 \mathrm{kcal} \mathrm{mol}^{-1}$ in the PCM model. The energy gap between the tautomers of 7 (Figure 4) is $0.9 \mathrm{kcal} \mathrm{mol}^{-1}$, suggesting that a substantial amount of the keto form is available. Intramolecular hydrogen bonding with the piperidine moiety in $\mathbf{3}$ leads to stabilization of the enol form by $2 \mathrm{kcal} \mathrm{mol}^{-1}$. Although the effect of the cyano group on the phenyl ring should shift the equilibrium to the keto form, the action of the side moiety proves to be much more effective in stabilizing the enol form (Scheme 2). In a comparison of the neutral forms $\mathbf{2}$ and $\mathbf{3}$, the piperidine-enol stabilization effect is weaker in $\mathbf{3}$, as expected (7.8 vs. $5.2 \mathrm{kcal} \mathrm{mol}^{-1}$; Figures 3 and 4). It is also expected that compared to $\mathbf{2}$, protonation of $\mathbf{3}$ stabilizes the keto form even more-the energy gap between the tautomers is $-3.9 \mathrm{kcal}$ $\mathrm{mol}^{-1}$. The observed effects for compounds with a nitro substituent (4 and 8) are similar (Figure S26). As seen in Figures 3 and 4 , the zwitterionic structures are highly destabilized in the gas phase in all cases, with values of 16,12 and $14 \mathrm{kcal} \mathrm{mol}^{-1}$ for 2-4, respectively. Accounting for the solvent effect, substantial stabilization of these zwitterions can be predicted for $\mathbf{2}$ (Figure 3), 3 (Figure 5) and 4 (Figure S27). However, in the case of the latter two compounds, the energy difference between the enol form and the zwitterion form is 0.9 and $0.5 \mathrm{kcal} \mathrm{mol}^{-1}$ respectively, which suggests that both coexist in solution. Consequently, decreasing the $\mathrm{pH}$ seems to be a suitable method to shift the tautomeric equilibrium of 2 from the pure enol to the pure keto form, and in the cases of $\mathbf{3}$ and $\mathbf{4}$ from zwitterionic structure to pure keto form.

Compound 2 crystallizes in the monoclinic space group C2/ c with one molecule per asymmetric unit (Figure 6a). The phenyl and naphthalene rings in $\mathbf{2}$ are nearly planar [RMS of $0.0039(2)$ and $0.019(8) \AA$, respectively]. The angle between the mean planes of the rings systems was $5.8(2)^{\circ}$. The results from the X-ray analysis of $\mathbf{2}$ clearly show that the enol form is observed in the solid state (Figure 6a). An intramolecular hydrogen bond between the $\mathrm{N}$ atom of the piperidine moiety and

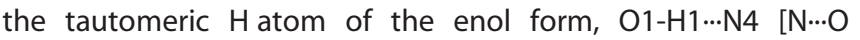
2.629(4) $\AA, \mathrm{O}-\mathrm{H} 0.761(4) \AA, \mathrm{N}-\mathrm{H}-\mathrm{O} 136.1(2)^{\circ}$ ], stabilizes the molecular structure. Irrespective of the influence of the EWG on 


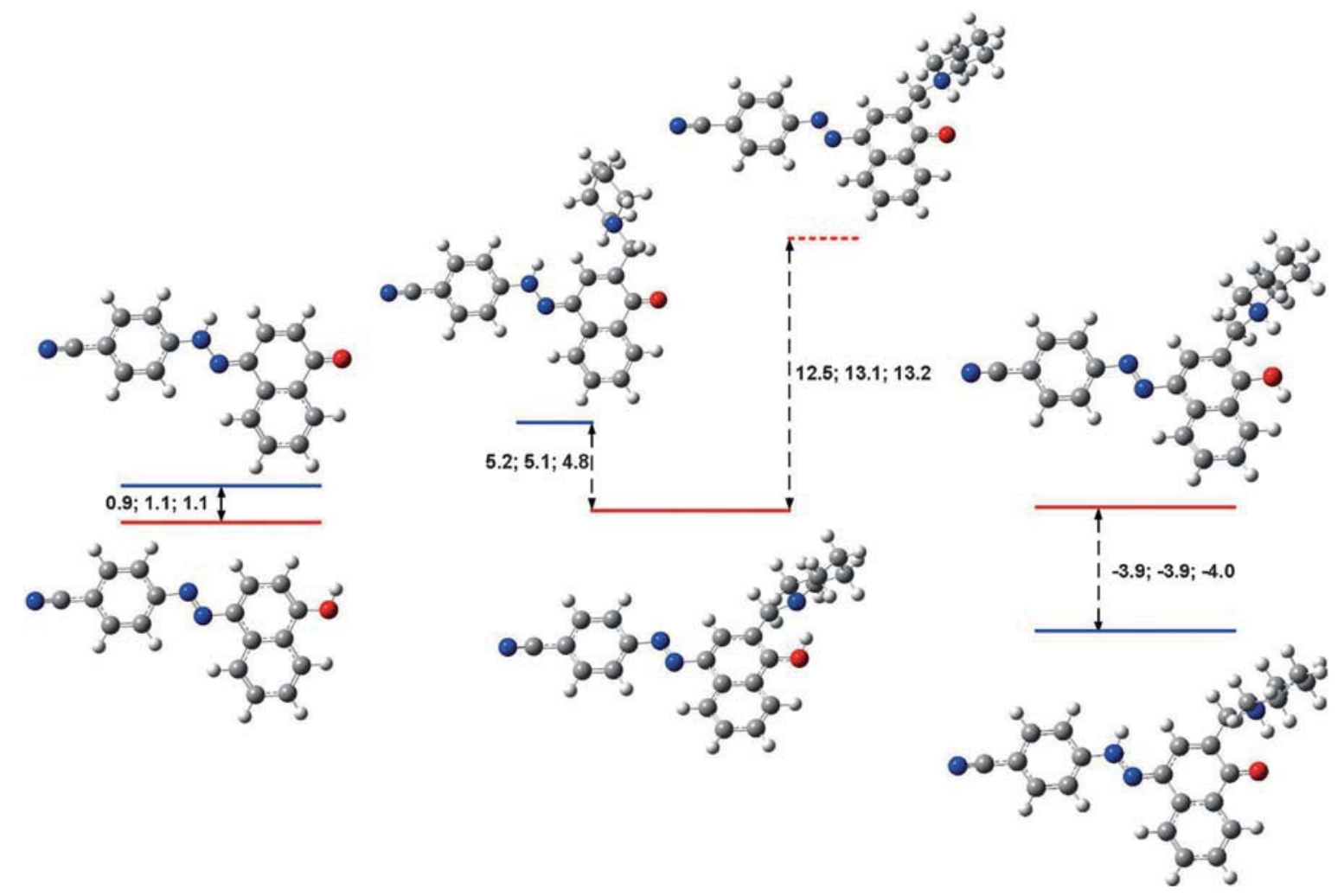

Figure 4. Change in the relative energy (M06-2X/def2-TZVP) of the tautomers of the parent compounds $\mathbf{7}$ (left), $\mathbf{3}$ (center) and $\mathbf{3} \mathbf{H}^{+}$(right) in the gas phase. The values of $\Delta E, \Delta E+Z P E$ and $\Delta \Delta G$ are expressed in $\mathrm{kcal} \mathrm{mol}^{-1}$.

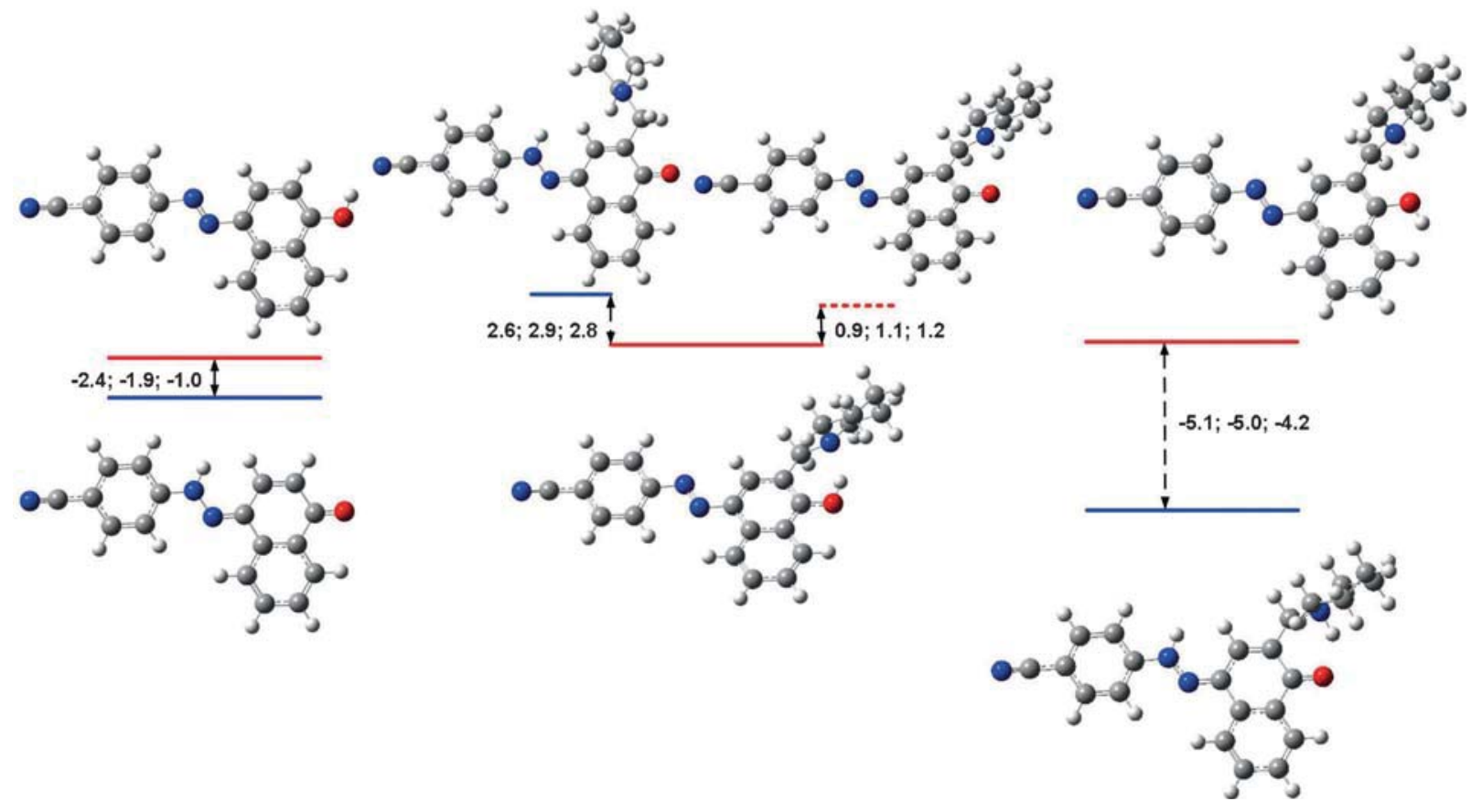

Figure 5. Change in the relative energy (M06-2X/def2-TZVP) of the tautomers of the parent compounds $\mathbf{7}$ (left), $\mathbf{3}$ (center) and $\mathbf{3} \mathbf{H}^{+}$(right) in acetonitrile (PCM field). The values of $\Delta E, \Delta E+Z P E$ and $\Delta \Delta G$ are expressed in $\mathrm{kcal} \mathrm{mol}^{-1}$.

the phenyl ring of the azo dye, refinement of compounds 3 and 4 also leads to the enol form (Figure $6 \mathrm{~b}$ and $\mathrm{c}$ ). The majority of the bond lengths and angles values are comparable for
2, 3 and 4 (Table 2). It is apparent that, in the case of compounds $\mathbf{2}, \mathbf{3}$ and $\mathbf{4}$ in the solid state, the molecular stabilization is dominated by the formation of the observed internal hydro- 
a)

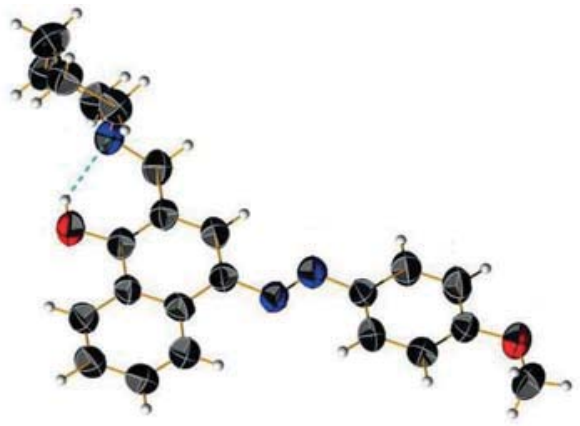

b)

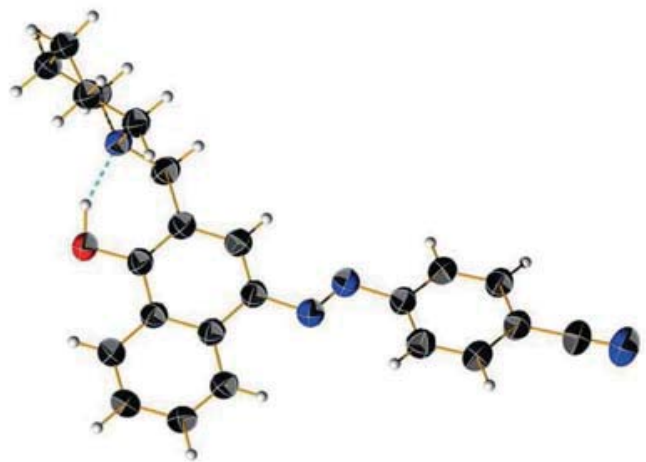

c)

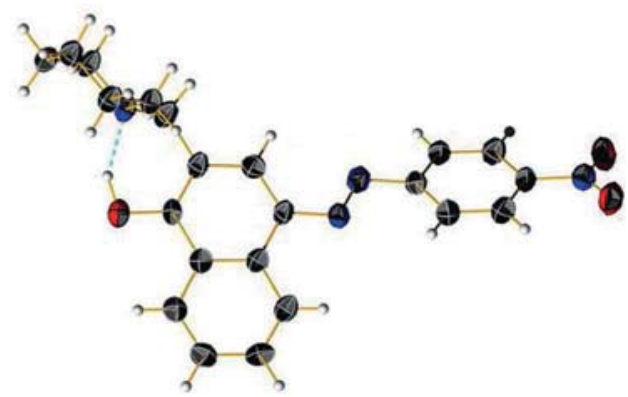

Figure 6. The molecular structures of compounds $\mathbf{2}$ (a), $\mathbf{3}$ (b) and $\mathbf{4}$ (c), with atomic displacement parameters (ADP) at $50 \%$ probability. $\mathrm{H}$ atoms are shown as spheres of arbitrary radii. The internal hydrogen bond (O1$\mathrm{H} 1 \cdots \mathrm{N} 4)$ is shown as a dashed blue line.

gen bond, whereas the stabilization/destabilization effect of the substituents on the phenyl ring is minimized (Figure 7).

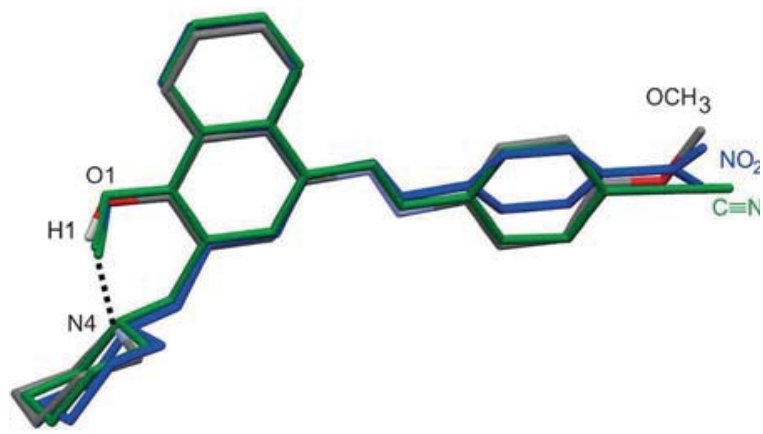

Figure 7. Overlay of the structures of $\mathbf{2 , 3}$ and $\mathbf{4}$, showing the conserved internal hydrogen bond $\mathrm{O} 1-\mathrm{H} 1 \cdots \mathrm{N} 4$ and the presence of slight structural variations due to the different substituents.

\begin{tabular}{|lllll|}
\hline \multicolumn{5}{|l}{$\begin{array}{l}\text { Table 2. Selected bond lengths and angles as a function of the substitu- } \\
\text { ent in 1-4 (see Scheme 5 for the atom numbering). }\end{array}$} \\
Substituent & $\mathrm{H}$ & $\mathrm{OMe}$ & $\mathrm{CN}$ & $\mathrm{NO}_{2}$ \\
\hline Compound & $\mathbf{1}^{\text {[10] }}$ & $\mathbf{2}$ & $\mathbf{3}$ & 4 \\
Bond length [A] & & & & \\
C1-N1 & $1.428(3)$ & $1.429(4)$ & $1.421(3)$ & $1.444(5)$ \\
N1=N2 & $1.262(3)$ & $1.251(3)$ & $1.264(3)$ & $1.269(4)$ \\
N2-C7 & $1.410(3)$ & $1.425(4)$ & $1.406(3)$ & $1.419(5)$ \\
C14-O1 & $1.360(3)$ & $1.355(3)$ & $1.358(3)$ & $1.356(4)$ \\
C16-C17 & $1.520(4)$ & $1.499(4)$ & $1.514(3)$ & $1.506(5)$ \\
C17-N4 & $1.481(3)$ & $1.463(3)$ & $1.468(3)$ & $1.471(5)$ \\
N4-C18 & $1.477(3)$ & $1.474(4)$ & $1.482(3)$ & $1.458(5)$ \\
N4-C22 & $1.471(2)$ & $1.470(4)$ & $1.476(3)$ & $1.479(5)$ \\
O1-H & $0.993(3)$ & $0.761(4)$ & $1.070(3)$ & $1.090(6)$ \\
Angle [ $]$ & & & & \\
C1-N1=N2 & $114.1(2)$ & $113.4(3)$ & $114.1(2)$ & $111.9(3)$ \\
N1=N2-C7 & $114.9(2)$ & $114.4(3)$ & $114.9(2)$ & $114.4(4)$ \\
N2-C7-C8 & $117.0(2)$ & $115.8(3)$ & $116.7(2)$ & $115.5(4)$ \\
O1-C14-C15 & $121.5(2)$ & $121.2(3)$ & $121.2(2)$ & $120.2(4)$ \\
C14C15-C17 & $121.3(2)$ & $121.7(3)$ & $120.2(2)$ & $120.5(3)$ \\
C15-C17-N4 & $112.0(2)$ & $113.2(3)$ & $112.8(2)$ & $111.6(3)$ \\
Torsion angle [ $\left.{ }^{\circ}\right]$ & & & & \\
C1-N1=N2-C7 & $-174.2(2)$ & $-179.5(2)$ & $-177.5(2)$ & $-176.7(3)$ \\
O1-C14-C16-C17 & $-4.8(3)$ & $-4.9(4)$ & $4.3(3)$ & $2.2(6)$ \\
N4-C17-C16-C14 & $42.7(3)$ & $35.5(4)$ & $-39.9(3)$ & $-41.7(5)$ \\
C1-C2-C3-C4 & $0.4(3)$ & $1.1(5)$ & $-0.7(4)$ & $-2.8(6)$ \\
C7-C8-C9-C10 & $177.7(1)$ & $177.5(3)$ & $178.6(2)$ & $176.4(4)$ \\
\hline
\end{tabular}

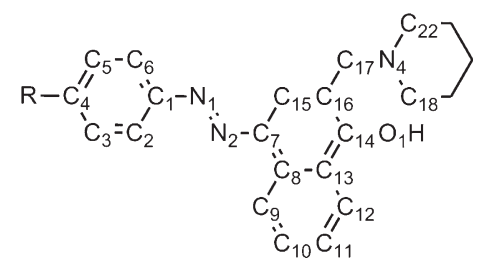

Scheme 5. Numbering of the atoms involved in intramolecular hydrogen bonding.

As seen in Table 2, although the zwitterionic structure is not observed in the solid state, there is a clear trend towards the elongation of the $\mathrm{O}-\mathrm{H}$ bond and shortening of the distance between the piperidine $\mathrm{N} 4$ and $\mathrm{H}$ atoms. The length of the C14-01 bond remains almost unchanged, but a tendency towards elongation of the $\mathrm{N} 1=\mathrm{N} 2$ bond, far from the corresponding values for the keto tautomers, ${ }^{[10]}$ could be also seen from EDG to EWG substitution, as a result of the increased zwitterionic nature of the compounds.

\section{Conclusions}

The possibilities for molecular switching of a series of tautomeric azonaphthols were investigated using molecular spectroscopy, X-ray analysis, and density functional theory (DFT) quantum chemical calculations. Two opposite effects on the on-off transition exist: hydrogen-bonding stabilization of the attached piperidine sidearm and the electronic action of the substituents on the phenyl ring. We found that the effect of the piperidine moiety dominates as a whole, but for com- 
pounds with strong electron-acceptor substituents on the phenyl ring, the enol form exists as a zwitterion.

\section{Experimental Section}

\section{General}

All reagents were purchased from Sigma-Aldrich and Merck, and were used without further purification. Silica gel TLC plates (Fluka 60778, Sigma-Aldrich) with fluorescent indicator $(254 \mathrm{~nm})$ were used for thin-layer chromatography and determining of $R_{\mathrm{f}}$ values. Merck silica gel $60(0.040-0.063 \mathrm{~mm})$ was used for flash chromatography purification of the products. Melting points were determined in capillary tubes on an MPA100 OptiMelt automated melting point system (SRS, Sunnyvale, CA). NMR spectra were recorded on a Bruker Avance II $+600 \mathrm{MHz}$ spectrometer at $25^{\circ} \mathrm{C}$. Chemical shifts $(\delta)$ are expressed in ppm relative to the internal standard tetramethylsilane, and coupling constants are expressed in $\mathrm{Hz}$. Signal assignments were confirmed by applying $2 \mathrm{D}$ techniques. The spectra were recorded as $10^{-1} \mathrm{M}$ solutions in $\mathrm{CDCl}_{3}$ except in NOESY experiments, for which $3 \times 10^{-2} \mathrm{M}$ solutions were used in order to avoid intermolecular interactions. The spectra were processed with the Topspin 2.1 program.

\section{Synthesis}

Compounds 2-4 were obtained by Mannich reaction of the parent azo dyes 6-8, respectively, which were prepared by classical diazo coupling of 1-naphthol and diazotized 4-substituted anilines. The $\mathrm{N}$-Me derivative of $\mathbf{7}$ was synthesized by methylation of the latter. The NMR spectra are provided in the Supporting Information (Figures S1-S24).

\section{Synthesis of Compounds 6-8}

Ice, conc. aq. $\mathrm{HCl}(1.2 \mathrm{~mL})$, and $\mathrm{NaNO}_{2}(4.4 \mathrm{mmol})$ were sequentially added to the 4-substituted aniline $(4 \mathrm{mmol})$ and the mixture was stirred at $0^{\circ} \mathrm{C}$ for $5 \mathrm{~min}$ to form the diazonium salt. This mixture was added to a solution of naphthalen-1-ol $(4 \mathrm{mmol})$ in $10 \%$ aq. $\mathrm{NaOH}(10 \mathrm{~mL})$ at $0^{\circ} \mathrm{C}$. The residue formed was filtered off, washed with water and dried in air to give the 4-(aryldiazenyl)naphthalen1 -ol, which was used for the corresponding preparation of compounds 2-4 without further purification. Samples were purified for spectroscopic experiments by flash chromatography on silica gel (100\% $\mathrm{CH}_{2} \mathrm{Cl}_{2}$ to $\mathrm{CH}_{2} \mathrm{Cl}_{2}$ /acetone 95:5). The melting points of the products were identical to literature values: 4-[(4-methoxyphenyl)diazenyl]naphthalen-1-ol 6: m.p. $164.8-165.1^{\circ} \mathrm{C}$ (Ref. ${ }^{[11]}$ 167$\left.168^{\circ} \mathrm{C}\right)$; 4-[(4-cyanophenyl)diazenyl]naphthalen-1-ol 7: m.p. 253.6$253.8^{\circ} \mathrm{C}$ (Ref. $\left.{ }^{[12]} 254-256^{\circ} \mathrm{C}\right)$; 4-[(4-nitrophenyl)diazenyl]naphthalen1-ol 8: m.p. $282.7-283.1^{\circ} \mathrm{C}$ (Ref. ${ }^{[13]} 287-289^{\circ} \mathrm{C}$ ).

\section{Synthesis of Compounds 2-4}

Paraformaldehyde $(3.3 \mathrm{mmol}), p$-toluenesulfonic acid $(20 \mathrm{mg})$, and crude azo dye 6-8 $(3 \mathrm{mmol})$ were added sequentially to a solution of piperidine $(3.3 \mathrm{mmol})$ in benzene $(20 \mathrm{~mL})$, and the mixture was heated at reflux with stirring for $1 \mathrm{~h}$. The products were partitioned between benzene and water. The organic phase was dried $\left(\mathrm{Na}_{2} \mathrm{SO}_{4}\right)$, evaporated to dryness, and the residue was purified by flash chromatography on silica gel.

2-(Piperidinomethyl)-4-[(4-methoxyphenyl)diazenyl]naphthalen-1-ol (2): Red crystals, $92 \%$ overall yield; $R_{\mathrm{f}}=0.39$ (acetone $/ \mathrm{CH}_{2} \mathrm{Cl}_{2}$
10:90); m.p. $135.3-135.6^{\circ} \mathrm{C}$; ${ }^{1} \mathrm{H}$ NMR $(600 \mathrm{MHz}): \delta=1.703$ (brs, $6 \mathrm{H}$; $\mathrm{CH}_{2}-3, \mathrm{CH}_{2}-4$ and $\mathrm{CH}_{2}-5$ piperidine), 2.164 (brs, $2 \mathrm{H} ; \mathrm{CH}-2$ and $\mathrm{CH}-6$ piperidine), 3.073 (brs, $2 \mathrm{H} ; \mathrm{CH}-2$ and $\mathrm{CH}-6$ piperidine), 3.904 (s, $\left.3 \mathrm{H} ; \mathrm{OCH}_{3}\right), 3.910\left(\mathrm{~s}, 2 \mathrm{H} ; \mathrm{ArCH}_{2} \mathrm{~N}\right), 7.046(\mathrm{~d}, J=9.0 \mathrm{~Hz}, 2 \mathrm{H} ; \mathrm{CH}-3$ and $\mathrm{CH}-5 \mathrm{MeOPh}$ ), 7.554 (ddd, $J=8.2,6.7,1.2 \mathrm{~Hz}, 1 \mathrm{H} ; \mathrm{CH}-8 \mathrm{Ar}$ ), 7.628 (ddd, $J=8.4,6.7,1.3 \mathrm{~Hz}, 1 \mathrm{H} ; \mathrm{CH}-7 \mathrm{Ar}$ ), 7.667 (s, $1 \mathrm{H} ; \mathrm{CH}-3 \mathrm{Ar}$ ), $7.999(\mathrm{~d}, J=9.0 \mathrm{~Hz}, 2 \mathrm{H} ; \mathrm{CH}-2$ and $\mathrm{CH}-6 \mathrm{MeOPh}$ ), 8.311 (ddd, J=8.3, $1.2,0.7 \mathrm{~Hz}, 1 \mathrm{H} ; \mathrm{CH}-9 \mathrm{Ar}), 8.938(\mathrm{~d}, J=8.4 \mathrm{~Hz}, 1 \mathrm{H} ; \mathrm{CH}-6 \mathrm{Ar})$, 10.055 ppm (brs, $1 \mathrm{H} ; \mathrm{OH}) ;{ }^{13} \mathrm{C} \mathrm{NMR}\left(150 \mathrm{~Hz}: \delta=23.91\left(\mathrm{CH}_{2}-4\right.\right.$ piperidine), $25.81\left(\mathrm{CH}_{2}-3\right.$ and $\mathrm{CH}_{2}-5$ piperidine $), 53.95\left(\mathrm{CH}_{2}-2\right.$ and $\mathrm{CH}_{2}-6$ piperidine), $55.60\left(\mathrm{OCH}_{3}\right), 62.18\left(\mathrm{ArCH}_{2} \mathrm{~N}\right), 112.95(\mathrm{CH}-3 \mathrm{Ar}), 114.07$ (Cquat-2), 114.23 (CH-3 and $\mathrm{CH}-5 \mathrm{MeOPh}), 122.21$ (CH-9 Ar), 123.01 (CH-6 Ar), $124.41(\mathrm{CH}-2$ and $\mathrm{CH}-6 \mathrm{MeOPh}), 125.04\left(\mathrm{C}_{\text {quat }}-10\right), 125.32$ $(\mathrm{CH}-8 \mathrm{Ar}), 126.99(\mathrm{CH}-7 \mathrm{Ar}), 132.33\left(\mathrm{C}_{\text {quat }}-5\right), 140.01\left(\mathrm{C}_{\text {quat }}-4\right), 147.88$ $\left(C_{\text {quat }}-1 \mathrm{MeOPh}\right), 158.02\left(\mathrm{C}_{\text {quat }}-1\right), 161.29 \mathrm{ppm}\left(\mathrm{C}_{\text {quat }}-4 \mathrm{MeOPh}\right) ; \mathrm{COSY}$ cross peaks: $\delta=7.046 / 7.999,7.554 / 7.628,7.554 / 8.311,7.628 /$ 8.938 ppm; NOESY cross peaks: $\delta=3.904 / 7.046,3.910 / 7.667,3.910 /$ $10.055,7.046 / 7.999,7.554 / 7.628,7.554 / 8.311,7.628 / 8.938$ ppm; HSQC cross peaks: $\delta=1.703 / 23.91,1.703 / 25.81,2.164 / 53.95,3.073 /$ 53.95, 3.904/55.60, 3.910/62.18, 7.046/114.23, 7.554/125.32, 7.628/ $126.99,7.667 / 112.95,7.999 / 124.41,8.311 / 122.21,8.938 / 123.01$ ppm; HMBC cross peaks: $\delta=1.703 / 23.91,1.703 / 25.81,1.703 / 53.95,3.904 /$ 114.23, 3.904/161.29, 3.910/53.95, 3.910/112.95, 3.910/114.07, 7.046/ 114.23， 7.046/147.88, 7.046/161.29 (weak), 7.554/123.01, 7.554/ $125.04,7.628 / 122.21,7.628 / 132.33,7.667 / 62.18,7.667 / 132.33$, 7.667/140.01 (weak), 7.667/158.02, 7.999/124.41, 7.999/147.88 (weak), 7.999/161.29, 8.311/126.99, 8.311/132.33, 8.311/158.02, 8.938/125.04, 8.938/125.32, 8.938/140.01 ppm.

2-(Piperidinomethyl)-4-[(4-cyanophenyl)diazenyl]naphthalen-1-ol (3): Red crystals, $96 \%$ overall yield; $R_{\mathrm{f}}=0.16$ (acetone $/ \mathrm{CH}_{2} \mathrm{Cl}_{2}$ 20:80); m.p. $153.3-153.5^{\circ} \mathrm{C}$; ${ }^{1} \mathrm{H} \mathrm{NMR}(600 \mathrm{MHz}): \delta=1.716$ (brs, $6 \mathrm{H}$; $\mathrm{CH}_{2}-3, \mathrm{CH}_{2}-4$ and $\mathrm{CH}_{2}-5$ piperidine), 2.242 (brs, $2 \mathrm{H} ; \mathrm{CH}-2$ and $\mathrm{CH}-6$ piperidine), 3.088 (brs, $2 \mathrm{H}, \mathrm{CH}-2$ and $\mathrm{CH}-6$ piperidine), 3.924 (s, $2 \mathrm{H}$, $\mathrm{ArCH}_{2} \mathrm{~N}$ ), 7.558 (ddd, $J=8.2,6.8,1.2 \mathrm{~Hz}, 1 \mathrm{H} ; \mathrm{CH}-8 \mathrm{Ar}$ ), 7.652 (ddd, $J=8.4,6.8,1.3 \mathrm{~Hz}, 1 \mathrm{H}$; CH-7 Ar), $7.790(\mathrm{~m}, 3 \mathrm{H}$; CH-3 Ar and $\mathrm{CH}-3$ and $\mathrm{CH}-5 \mathrm{PhCN}), 8.004(\mathrm{~d}, J=8.9,2 \mathrm{H} ; \mathrm{CH}-2$ and $\mathrm{CH}-6 \mathrm{PhCN}), 8.310$ (ddd, $J=8.4,1.2,0.6 \mathrm{~Hz}, 1 \mathrm{H} ; \mathrm{CH}-9 \mathrm{Ar}$ ), $8.897(\mathrm{~d}, J=8.4 \mathrm{~Hz}, 1 \mathrm{H} ; \mathrm{CH}-$ $6 \mathrm{Ar}), 10.049 \mathrm{ppm}(\mathrm{brs}, 1 \mathrm{H} ; \mathrm{OH}) ;{ }^{13} \mathrm{C} \mathrm{NMR}(150 \mathrm{~Hz}): \delta=23.74\left(\mathrm{CH}_{2}{ }^{-}\right.$ 4 piperidine), $25.65\left(\mathrm{CH}_{2}-3\right.$ and $\mathrm{CH}_{2}-5$ piperidine $), 53.85\left(\mathrm{CH}_{2}-2\right.$ and $\mathrm{CH}_{2}-6$ piperidine), $61.91\left(\mathrm{ArCH}_{2} \mathrm{~N}\right), 112.30\left(\mathrm{C}_{\text {quat }}-4 \mathrm{PhCN}\right), 114.43(\mathrm{CH}-$ $3 \mathrm{Ar}), 118.94\left(\mathrm{C}_{\text {quat }}-2\right), 122.61(\mathrm{CH}-9 \mathrm{Ar}), 122.67(\mathrm{CH}-2$ and $\mathrm{CH}-6$ $\mathrm{PhCN}), 122.98(\mathrm{CH}-6 \mathrm{Ar}$ and $\mathrm{CN}), 125.19\left(\mathrm{C}_{\text {quat }}-10\right), 125.66(\mathrm{CH}-8 \mathrm{Ar})$, $127.99(\mathrm{CH}-7 \mathrm{Ar}), 133.13\left(\mathrm{C}_{\text {quat }}-5\right), 133.22(\mathrm{CH}-3$ and $\mathrm{CH}-5 \mathrm{PhCN})$, $139.55\left(C_{\text {quat }}-4\right), 155.34\left(C_{\text {quat }}-1 \mathrm{PhCN}\right), 161.50 \mathrm{ppm}\left(\mathrm{C}_{\text {quat }}-1\right) ; \operatorname{COSY}$ cross peaks: $\delta=7.558 / 7.652,7.558 / 8.310,7.652 / 8.897,7.790 /$ 8.004 ppm; NOESY cross peaks: $\delta=3.924 / 2.242,3.924 / 3.088,3.924 /$ $7.790,7.558 / 7.652,7.558 / 8.310,7.652 / 8.897,7.790 / 8.004,7.790 /$ $114.43, \quad 7.790 / 133.22, \quad 8.004 / 122.98, \quad 8.310 / 122.61, \quad 8.897 /$ 122.67 ppm; HSQC cross peaks: $\delta=1.716 / 23.74,1.716 / 25.65,2.242 /$ 53.85, 3.088/53.85, 3.924/61.91, 7.558/125.66, 7.652/127.99 ppm; HMBC cross peaks: $\delta=3.924 / 53.85,3.924 / 114.43,3.924 / 139.55$ (weak), 3.924/161.50, 7.558/122.67, 7.558/125.19, 7.652/122.61, 7.652/133.13, 7.790/61.91, 7.790/118.94, 7.790/122.98 (weak), 7.790/ 133.22, 7.790/155.34, 7.790/161.50 (weak), 8.004/112.30, 8.004/ $122.67,8.004 / 122.98,8.004 / 133.22$ (weak), 8.004/155.34 (weak), $8.310 / 127.99,8.310 / 133.13,8.310 / 161.50,8.897 / 125.19,8.897 /$ $125.66,8.897 / 139.55 \mathrm{ppm}$.

2-(Piperidinomethyl)-4-[(4-nitrophenyl)diazenyl]naphthalen-1-ol (4): Red crystals, 89\% yield; $R_{\mathrm{f}}=0.18$ (EtOAc/Et $\left.{ }_{3} \mathrm{~N} 100: 1\right) ;$ m.p. 162.9163.2 ${ }^{\circ} \mathrm{C}$ (Ref. ${ }^{[14]} 232-233^{\circ} \mathrm{C}$ as $\mathrm{HCl}$ salt); ${ }^{1} \mathrm{H}$ NMR: $\delta=1.722$ (brs, $6 \mathrm{H} ; \mathrm{CH}_{2}-3, \mathrm{CH}_{2}-4$ and $\mathrm{CH}_{2}-5$ piperidine), 2.215 (brs, $2 \mathrm{H} ; \mathrm{CH}-2$ and $\mathrm{CH}-6$ piperidine), 3.098 (brs, $2 \mathrm{H} ; \mathrm{CH}-2$ and $\mathrm{CH}-6$ piperidine), 3.935 
(s, $2 \mathrm{H} ; \mathrm{ArCH}_{2} \mathrm{~N}$ ), 7.565 (ddd, J=8.2, 6.7, $1.2 \mathrm{~Hz}, 1 \mathrm{H} ; \mathrm{CH}-8 \mathrm{Ar}$ ), 7.667 (ddd, J=8.3, 6.7, 1.3 Hz, 1 H; CH-7 Ar), $7.813(\mathrm{~s}, 1 \mathrm{H} ; \mathrm{CH}-3 \mathrm{Ar}$ ), 8.034 (d, $J=8.9 \mathrm{~Hz}, 2 \mathrm{H} ; \mathrm{CH}-2$ and $\left.\mathrm{CH}-6 \mathrm{PhNO}_{2}\right), 8.316(\mathrm{~d}, J=8.2 \mathrm{~Hz}, 1 \mathrm{H}$; CH-9 Ar), 8.364 (d, J=9.0 Hz, 2H; CH-3 and CH-5 PhNO $)_{2}, 8.916$ (d, $J=8.4 \mathrm{~Hz}, 1 \mathrm{H}$; $\mathrm{CH}-6 \mathrm{Ar}), 10.448 \mathrm{ppm}$ (brs, $1 \mathrm{H} ; \mathrm{OH}) ;{ }^{13} \mathrm{C} \mathrm{NMR}$ $(150 \mathrm{~Hz}): \delta=23.73\left(\mathrm{CH}_{2}-4\right.$ piperidine $), 25.65\left(\mathrm{CH}_{2}-3\right.$ and $\mathrm{CH}_{2}-5$ piperidine), $53.83\left(\mathrm{CH}_{2}-2\right.$ and $\mathrm{CH}_{2}-6$ piperidine $), 61.94\left(\mathrm{ArCH}_{2} \mathrm{~N}\right), 113.88$ $\left(\mathrm{C}_{\text {quat }}-2\right), 114.64(\mathrm{CH}-3 \mathrm{Ar}), 122.67\left(\mathrm{CH}-2\right.$ and $\left.\mathrm{CH}-6 \mathrm{PhNO}_{2}\right), 122.92$ $(\mathrm{CH}-6$ and $\mathrm{CH}-9 \mathrm{Ar}), 124.83\left(\mathrm{CH}-3\right.$ and $\left.\mathrm{CH}-5 \mathrm{PhNO}_{2}\right), 125.23\left(\mathrm{C}_{\text {quat }}{ }^{-}\right.$ 10), $125.69(\mathrm{CH}-8 \mathrm{Ar}), 128.12(\mathrm{CH}-7 \mathrm{Ar}), 133.26\left(\mathrm{C}_{\text {quat }}-5\right), 139.67$ $\left(\mathrm{C}_{\text {quat }}-4\right), 147.61\left(\mathrm{C}_{\text {quat }}-4 \mathrm{PhNO}_{2}\right), 156.72\left(\mathrm{C}_{\text {quat }}-1 \mathrm{PhNO}_{2}\right), 161.89 \mathrm{ppm}$ $\left(\mathrm{C}_{\text {quat }}{ }^{-1)}\right.$; $\operatorname{COSY}$ cross peaks: $\delta=3.935 / 7.813,7.565 / 7.667,7.565 /$ $8.316,7.667 / 8.916,8.034 / 8.364$ ppm; HSQC cross peaks: $\delta=1.722 /$ $23.73,1.722 / 25.65,2.215 / 53.83,3.098 / 53.83,3.935 / 61.94,7.565 /$ $125.69, \quad 7.667 / 128.12,7.813 / 114.64,8.034 / 122.67,8.316 / 122.92$, $8.364 / 124.83,8.916 / 122.92 \mathrm{ppm}$; HMBC cross peaks: $\delta=1.722 /$ $23.73,1.722 / 25.65,1.722 / 53.83,3.935 / 53.83,3.935 / 113.88,3.935 /$ $114.64, \quad 3.935 / 161.89, \quad 7.565 / 122.92,7.565 / 125.23,7.667 / 122.92$, $7.667 / 133.26, \quad 7.813 / 133.26,7.813 / 139.67, \quad 7.813 / 161.89, \quad 8.034 /$ $124.83,8.034 / 147.61,8.034 / 156.72$ (weak), 8.316/133.26, 8.316/ $161.89,8.364 / 147.61$ (weak), 8.364/156.72, 8.916/139.67 ppm.

\section{Methylation of Azo Dye 7}

$\mathrm{KOH}(20 \mathrm{mmol})$ was added to a solution of $7(10 \mathrm{mmol})$ in tetrahydrofuran (THF, $50 \mathrm{~mL}$ ), and the mixture was stirred at room temperature for $15 \mathrm{~min} . \mathrm{CH}_{3} \mathrm{l}(50 \mathrm{mmol})$ was then added and the suspension was stirred for $2 \mathrm{~h}$. The solid phase was filtered and washed with THF. The solvent was removed in vacuo and the residue was purified by flash chromatography on silica gel $\left(100 \% \mathrm{CH}_{2} \mathrm{Cl}_{2}\right.$ to $\mathrm{CH}_{2} \mathrm{Cl}_{2}$ /acetone 98:2) to give the O-Me derivative of 2 as a less polar component, $R_{\mathrm{f}}=0.77\left(\mathrm{CH}_{2} \mathrm{Cl}_{2}\right)$, in $63 \%$ yield, and 4-[2-methyl2-(4-cyanophenyl)hydrazono]naphthalen-1-one ( $\mathrm{N}$-Me derivative of 7) as red crystals in $27 \%$ yield: $R_{\mathrm{f}}=0.39\left(\mathrm{CH}_{2} \mathrm{Cl}_{2}\right)$; m.p. 203.5203.8 ${ }^{\circ} \mathrm{C}$ (Ref. $\left.{ }^{[15]} 204-206^{\circ} \mathrm{C}\right) ;{ }^{1} \mathrm{H}$ NMR $(600 \mathrm{MHz}): \delta=3.794(\mathrm{~s}, 3 \mathrm{H}$; $\left.\mathrm{NCH}_{3}\right), 6.716(\mathrm{~d}, J=10.5 \mathrm{~Hz}, 1 \mathrm{H} ; \mathrm{CH}-2 \mathrm{Ar}), 7.430(\mathrm{~d}, J=9.1 \mathrm{~Hz}, 2 \mathrm{H}$; $\mathrm{CH}-2$ and $\mathrm{CH}-6 \mathrm{PhCN}), 7.532(\mathrm{~d}, J=10.5 \mathrm{~Hz}, 1 \mathrm{H} ; \mathrm{CH}-3 \mathrm{Ar}), 7.590$ (ddd, J=7.8, 7.3, 1.4 Hz, 1 H; CH-8 Ar), $7.671(\mathrm{~d}, J=9.1 \mathrm{~Hz}, 2 \mathrm{H} ; \mathrm{CH}-$ 3 and $\mathrm{CH}-5 \mathrm{PhCN}$ ), 7.695 (ddd, J=7.9, 6.3, $1.5 \mathrm{~Hz}, 1 \mathrm{H}$; $\mathrm{CH}-7 \mathrm{Ar}$ ), 8.208 (ddd, $J=7.8,1.5,0.5 \mathrm{~Hz}, 1 \mathrm{H} ; \mathrm{CH}-9 \mathrm{Ar}$ ), $8.408 \mathrm{ppm}$ (ddd, $J=$ 7.9, $1.4,0.5 \mathrm{~Hz}, 1 \mathrm{H} ; \mathrm{CH}-6 \mathrm{Ar}) ;{ }^{13} \mathrm{C}$ NMR $(150 \mathrm{~Hz}): \delta=45.47\left(\mathrm{NCH}_{3}\right)$ $104.90\left(\mathrm{C}_{\text {quat }}-4 \mathrm{PhCN}\right), 115.75(\mathrm{CH}-2$ and $\mathrm{CH}-6 \mathrm{PhCN}), 119.33(\mathrm{CN})$, 124.13 (CH-6 Ar), 126.25 (CH-9 Ar), 128.98 (CH-3 Ar), 129.51 (CH-8 $\mathrm{Ar}), 129.98(\mathrm{CH}-2 \mathrm{Ar}), 130.86\left(\mathrm{C}_{\text {quat }}-10\right), 132.60(\mathrm{CH}-7 \mathrm{Ar}), 133.35$ $(\mathrm{CH}-3$ and $\mathrm{CH}-5 \mathrm{PhCN}), 135.23\left(\mathrm{C}_{\text {quat }}-5\right), 142.03\left(\mathrm{C}_{\text {quat }}-4\right), 151.70$ $\left(\mathrm{C}_{\text {quat }}{ }^{-1} \mathrm{PhCN}\right), 184.70 \mathrm{ppm}\left(\mathrm{C}_{\text {quat }}-1\right) ; \operatorname{COSY}$ cross peaks: $\delta=6.706 /$ $7.532,7.430 / 7.671,7.590 / 7.695,7.590 / 8.208,7.695 / 8.408$ ppm; NOESY cross peaks: $\delta=3.794 / 7.430,3.794 / 7.532,6.706 / 7.532$, 7.430/7.671, 7.430/8.408 (weak), 7.590/7.695, 7.590/8.208, 7.695/ 8.408 ppm; HSQC cross peaks: $\delta=3.794 / 45.47,6.706 / 129.98,7.430 /$ $115.75,7.532 / 128.98,7.590 / 129.51,7.671 / 133.35,7.695 / 132.60$, $8.208 / 126.25,8.408 / 124.13 \mathrm{ppm}$; HMBC cross peaks: $\delta=3.794 /$ $115.75,3.794 / 151.70,6.706 / 126.25$ (weak), 6.706/130.86, 6.706/ 135.23 (weak), 6.706/142.03, 7.430/104.90, 7.430/115.75, 7.430/ 119.33 (weak), 7.430/133.35 (weak), 7.430/151.70, 7.532/124.13, $7.532 / 129.98,7.532 / 135.23,7.532 / 142.03,7.532 / 184.70, \quad 7.590 /$ 124.13, 7.590/130.86, 7.590/135.23 (weak), 7.671/115.75 (weak), $7.671 / 119.33,7.671 / 133.35,7.671 / 151.70,7.695 / 126.25,7.695 /$ $135.23,8.208 / 132.60,8.208 / 135.23,8.208 / 184.70,8.408 / 129.51$, $8.408 / 130.86,8.408 / 142.03 \mathrm{ppm}$.

\section{Spectral Measurements}

The UV/Vis spectra were measured on a JASCO V-570 UV/Vis/NIR spectrophotometer, equipped with a Julabo ED5 thermostat (precision $1{ }^{\circ} \mathrm{C}$ ) at $20^{\circ} \mathrm{C}$ with spectral grade anhydrous acetonitrile (dried over $\mathrm{P}_{2} \mathrm{O}_{5}$, distilled over $\mathrm{CaH}_{2}$ and stored over molecular sieves ${ }^{[16]}$ ). Sulfuric acid (96\%) was used to protonate the azo dyes in acetonitrile and the $\mathrm{pH}$ values were measured using a Metrohm $654 \mathrm{pH}$ meter.

\section{Crystallographic Measurements}

A crystal of $\mathbf{2}$ was mounted of on a glass capillary, and all geometric and intensity data were taken from this crystal. Data collection using MoK $\alpha$ radiation $(\lambda=0.71073 \AA)$ was performed at room temperature on an Agilent SuperNova (Dual Source) diffractometer equipped with an Atlas CCD detector. The determination of the unit cell parameters, data reduction and absorption correction (multiscan) was performed using CrysAlisPro ${ }^{[17]}$ software. Crystals of 3 and $\mathbf{4}$ were mounted on loops, and all geometric and intensity data were measured using these crystals. Data collection using MoK $\alpha$ radiation $(\lambda=0.71073 \AA)$ was performed at room temperature on a STOE IPDS2 diffractometer equipped with an Oxford cryostat. Determination of the unit cell parameters and data reduction were performed using X-Area ${ }^{[18]}$ software. Structures were solved with SHELXS-97 and refined using full-matrix least-squares on $\mathrm{F}^{2}$ with the SHELXL-97 package ${ }^{[19]}$.

Crystal data of 2: Monoclinic; C2/C (No. 15), $a=34.716(8), b=$ 5.994(4), $c=20.442(6) \AA ; \beta=105.63(2)^{\circ} ; V=4096(3) \AA^{3} ; Z=8 ; d=$ $1.218 \mathrm{mg} \mathrm{m}^{-3} ; 7696$ reflections measured; 4030 unique reflections, $R 1=0.0564[I>2 \sigma(l)] ; w R 2=0.1167$ (all data).

Crystal data of 3: Triclinic; P-1 (No. 2), $a=5.1014(8), \quad b=$ $11.5731(17), \quad c=16.653(3) \AA ; \quad \alpha=92.321(12), \quad \beta=93.662(2), \quad \gamma=$ $101.162(12)^{\circ} ; V=961.2(3) \AA^{3} ; Z=2 ; d=1.280 \mathrm{mg} \mathrm{m}^{-3} ; 11643$ reflections measured; 3169 unique reflections, $R 1=0.0439[I>2 \sigma(I)]$; $w R 2=0.1134$.

Crystal data of 4: Triclinic; P-1 (No. 2), $a=5.2175(7), \quad b=$ $10.7215(16), \quad c=17.295(3) \AA_{;} \quad \alpha=82.197(12), \quad \beta=81.572(12), \quad \gamma=$ $89.056(12)^{\circ} ; V=948.1(2) \AA^{3} ; Z=2 ; d=1.368 \mathrm{mg} \mathrm{m}^{-3} ; 12143$ reflections measured; 3347 unique reflections, $R 1=0.0605[I>2 \sigma(I)]$; $w R 2=0.1530$. Additional information is provided in Table S1.

CCDC-1008230 (2), 1024329 (3) and 928935 (4) contain the supplementary crystallographic data for this paper. These data can be obtained free of charge from The Cambridge Crystallographic Data Centre via www.ccdc.cam.ac.uk/data_request/cif.

\section{Quantum Chemical Calculations}

DFT and time-dependent (TD)-DFT ${ }^{[20]}$ were used to explore the ground- and excited-state properties of each molecule. For all cases, the solvent effect was described by applying the polarizable continuum model (PCM) in its integral equation formalism variant (IEFPCM). ${ }^{[21]}$ For ground-state calculations, an M06-2X-fitted hybrid meta-GGA functional ${ }^{[22]}$ and the def2-TZVP basis set ${ }^{[23]}$ were used. The M06-2X/def2-TZVP level of theory was shown to provide best results in predicting tautomerism of azonaphthols. ${ }^{[24]}$ All tautomeric forms of the investigated compounds were optimized without restrictions and then were characterized as true minima using vibrational frequency calculations. TD-DFT calculations were performed with both M06-2X and PBEO ${ }^{[25]}$ functionals. In particular, TD-M06$2 \mathrm{X} / 6-31 \mathrm{G}^{* *}$ and TD-PBE0/6-31G** levels of theory were used to 
compute vertical excitations. Quantum chemical calculations were performed using the Gaussian 09 program suite. ${ }^{[26]}$

\section{Acknowledgements}

The generous financial support by the Swiss National Science Foundation (SupraChem@Balkans.eu partnership under the SCOPES program), Alexander von Humboldt foundation, Bulgarian Science Fund (projects UNA-17/2005, DRNF-02-13/2009 and DRNF-02-01/2009) and CODECS-COST is gratefully acknowledged.

Keywords: chemometrics - density functional theory . molecular switches $\cdot$ spectroscopy $\cdot$ tautomerism

[1] a) C. C. Warford, V. Lemieux, N. R. Branda in Molecular Switches, 2nd ed (Eds.: B. L. Feringa, W. R. Browne) Wiley-VCH, Weinheim, 2011, pp. 1 15; b) M. Natali, S. Giordani, Chem. Soc. Rev. 2012, 41, 4010-4029.

[2] Molecular Machines and Motors, Structure and Bonding (Ed.: J.-P. Sauvage), Springer, Berlin/Heidelberg, 2001.

[3] P. J. Taylor, G. van der Zwan, L. Antonov in Tautomerism: Methods and Theories, 1st ed. (Ed.: L. Antonov), Wiley-VCH, Weinheim, 2013, chapter 1.

[4] a) P. Liljeroth, J. Repp, G. Meyer, Science 2007, 317, 1203-1206; b) F. Mohn, L. Gross, N. Moll, G. Meyer, Nat. Nanotechnol. 2012, 7, 227-31; c) H. Y. Lee, X. Song, H. Park, M.-H. Baik, D. Lee, J. Am. Chem. Soc. 2010, 132, 12133-12144; d) A. Farrera, I. Canal, P. Hidalgo-Fernandez, L. Perez-Garcia, O. Huertas, F. J. Luque, Chem. Eur. J. 2008, 14, 2277-2285; e) A. R. Todorov, M. Nieger, J. Helaja, Chem. Eur. J. 2012, 18, 7269-7277 f) Y. Ding, X. Li, J. P. Hill, K. Ariga, H. Ågren, J. Andréasson, W. Zhu, H. Tian, Y. Xie, Chem. Eur. J. 2014, 40, 12910-12916; g) T. Wijst, C. F. Guerra, M. Swart, F. M. Bickelhaupt, B. Lippert, Chem. Eur. J. 2008, 15 209-218; h) M. Juribašić, N. Bregović, V. Stilinović, V. Tomišić, M. Cindrić, P. Šket, J. Plavec, M. Rubčić, K. Užarević, Chem. Eur. J. 2014, DOI 10.1002/chem.201403543; i) P. A. Gale, J. R. Hiscock, N. Lalaoui, M. E. Light, N. J. Wellsa, M. Wenzela, Org. Biomol. Chem. 2012, 30, 59095915.

[5] a) L. Antonov, V. Deneva, S. Simeonov, V. Kurteva, D. Nedeltcheva, J. Wirz, Angew. Chem. Int. Ed. 2009, 48, 7875-7878; Angew. Chem. 2009, 121, 8015-8018; b) L. Antonov, V. Kurteva, S. Simeonov, V. Deneva, A Crochet, K. M. Fromm, Tetrahedron 2010, 66, 4292-4297; c) D. Nedeltcheva, L. Antonov, A. Lycka, B. Damyanova, S. Popov, Curr. Org. Chem. 2009, 13, 217-240.

[6] R. Kuhn, F. Bär, Justus Liebigs Ann. Chem. 1935, 516, 143-155.
[7] I. Ya Bershtein, O. F. Ginzburg, Russ. Chem. Rev. 1972, 41, 97-110.

[8] St. Stoyanov, L. Antonov, Dyes Pigm. 1988, 10, 33-45.

[9] S. Kawauchi, L. Antonov, Y. Okuno, Bulg. Chem. Commun. 2014, 46A, 228-237.

[10] L. Antonov, V. Kurteva, A. Crochet, L. Mirolo, K. M. Fromm, S. Angelova, Dyes Pigm. 2012, 92, 714-23.

[11] H. Shingu, Sci. Pap. Inst. Phys. Chem. Res. 1938, 35, 78-120.

[12] J. Schreiber, J. Kulič, J. Panchartek, M. Večeřa, Collect. Czech. Chem. Commun. 1971, 36, 3399-3403.

[13] R. Meldola, J. Chem. Soc. Trans. 1885, 47, 657-668.

[14] W. E. Hahn, J. Weglewski, Acta Chimica 1966, 11, 67-74.

[15] R. Hempel, H. Viola, J. Morgenstern, R. Mayer, J. Prakt. Chem. 1976, 18, $983-992$.

[16] J. A. Riddick, W. B. Bunger, T. K. Sakano, Organic Solvents: Physical Properties and Methods of Purification, 4th ed., Wiley, New York, 1986.

[17] CrysAlisPro, Agilent Technologies, UK Ltd, Yarnton, UK, 2011.

[18] X-Area, STOE \& Cie GmbH, Darmstadt, Germany, 2002.

[19] G. M. Sheldrick, Acta Crystallogr. Sect. A 2008, 64, 3112-3122.

[20] a) M. E. Casida, C. Jamorski, K. C. Casida, D. R. Salahub, J. Chem. Phys. 1998, 108, 4439-4449; b) R. E. Stratmann, G. E. Scuseria, M. J. Frisch, J. Chem. Phys. 1998, 109, 8218-8224; c) F. Furche, R. Ahlrichs, J. Chem. Phys. 2002, 117, $7433-7447$.

[21] J. Tomasi, B. Mennucci, R. Cammi, Chem. Rev. 2005, 105, 2999-3093.

[22] a) Y. Zhao, D. G. Truhlar, Theor. Chem. Acc. 2008, 120, 215-241; b) Y. Zhao, D. G. Truhlar, Acc. Chem. Res. 2008, 41, 157-167.

[23] F. Weigend, Phys. Chem. Chem. Phys. 2006, 8, 1057-1065.

[24] S. Kawauchi, L. Antonov, J. Phys. Org. Chem. 2013, 26, 643-652.

[25] a) C. Adamo, V. Barone, J. Chem. Phys. 1999, 110, 6158-6170; b) D. Jacquemin, V. Wathelet, E. A. Perpete, C. Adamo, J. Chem. Theory Comput. 2009, 5, 2420-2435.

[26] Gaussian 09 (Revision A.02), M. Frisch, G. Trucks, H. B. Schlegel, G. Scuseria, M. Robb, J. Cheeseman, G. Scalmani, V. Barone, B. Mennucci, G. Petersson, H. Nakatsuji, M. Caricato, X. Li, H. P. Hratchian, A. F. Izmaylov, J. Bloino, G. Zheng, J. L. Sonnenberg, M. Hada, M. Ehara, K. Toyota, R. Fukuda, J. Hasegawa, M. Ishida, T. Nakajima, Y. Honda, O. Kitao, H. Nakai, T. Vreven, J. A. Montgomery Jr., J. E. Peralta, F. Ogliaro, M. Bearpark, J. J. Heyd, E. Brothers, K. N. Kudin, V. N. Staroverov, R. Kobayashi, J. Normand, K. Raghavachari, A. Rendell, J.C. Burant, S. S. lyengar, J. Tomasi, M. Cossi, N. Rega, J. M. Millam, M. Klene, J. E. Knox, J. B. Cross, V. Bakken, C. Adamo, J. Jaramillo, R. Gomperts, R. E. Stratmann, O. Yazyev, A. J. Austin, R. Cammi, C. Pomelli, J. W. Ochterski, R. L. Martin, K. Morokuma, V. G. Zakrzewski, G. A. Voth, P. Salvador, J. J. Dannenberg, S. Dapprich, A. D. Daniels, O. Farkas, J. B. Foresman, J. V. Ortiz, J. Cioslowski, D. J. Fox, Gaussian, Inc., Wallingford, CT, 2009. 